\title{
Ambalajlı Ürünlerin Paket Üzerinde ve İnternet Ortamında Verilen Besin Ögesi Bilgilerinin Tutarlılı̆̆ı: Çikolata Örneği
}

\author{
Consistency of Nutritional Information Given on Packaged Products and Websites: Chocolate \\ as an Example
}

\section{Ayşe Tülay Bağcı Bosi' ${ }^{1}$, Zeynep Devran Muharremoğlu², Nasiman Alili ${ }^{3}$ Rudina Cengu ${ }^{4}$, Ahmad El Dandachli ${ }^{5}$, Hanife Selvi ${ }^{6}$, Tuğba Sarıcaoğlu ${ }^{7}$}

Geliş tarihi/Received: 18.09.2019 • Kabul tarihi/Accepted: 26.12.2019

\section{ÖZET}

Amaç: Bu çalışma ile süpermarketlerde satılan, bazı çikolata ve çikolatalı ürünlerin ürün ambalajında ve ürünün web sayfalarında verilen besin ögeleri ve içerik bilgilerinin incelenerek aynı ürünün ambalaj ve internet ortamda verilen besin ögesi ve içerik bilgilerinin tutarlılığını değerlendirilmek amaçlanmıştır.

Gereç ve Yöntem: Ankara Çankaya ilçesinde bulunan üç farklı süper markette satılan 88 çikolatalı ürünün, web sayfasında bilgisi bulunan 49'unun ambalaj ve ürün web sayfalarında verilen 100 gramlardaki toplam ve doymuş yağ, şeker, karbonhidrat, protein, tuz, enerji, lif ve içindekiler bilgileri karşllaştırılmıştır.

Bulgular: Çikolatalı ürünlerin \%75.5’inin paketinde \%44.8'inin web sayfasında besin ögesi içeriği bilgisi ve \%93.8'inin paketinde, \% 28.5'inin web sayfasında ise içindekiler bilgisinin bulunduğu belirlenmiştir. Ürünlerin 100 gramında ortalama $31.8 \pm 3.76 \mathrm{~g}$ toplam yağ ve $542.7 \pm 27.40 \mathrm{kkal}$ enerji bulunmaktadır. Çikolatalı ürünlerin paketlerinde ve web sayfalarında verilen besin içerik bilgilerinin (tam hidrojenize bitkisel yağ asidi, bitkisel yağ, kakao kitlesi, mısır nişastası, sodyum amonyak karbonat, peynir altı suyu tozu) içerikleri farklıdır ve istatistiksel olarak anlamlıdır $(\mathrm{p}<0.05)$.

Sonuç: İncelenen çikolatalı ürünlerin ambalaj ve web sayfalarında verilen enerji ve besin ögeleri bilgileri Spearman korelasyonla incelendiğinde korelasyon katsayısı R=1 olan ürün saptanmamıştır. Etiketleme yönetmeliğine göre tüm ambalajlı gıdalarda besin içeriği belirtilmeli, ürünlerin ambalaj ve dijital ortamda bilgileri tutarlı olmalıdır.

Anahtar kelimeler: Çikolata, gıda ambalajı, besin ögesi, içindekiler, internet sayfası

1. Hacettepe Üniversitesi Tıp Fakültesi Halk Sağlığı Anabilim Dalı, Ankara, Türkiye (1) https://orcid.org/0000-0003-2487-8099

2. İletişim/Correspondence: Hacettepe Üniversitesi Tıp Fakültesi Halk Sağlığı Anabilim Dall, Ankara, Türkiye

E-posta: zynpdvrn@gmail.com • ํ) https://orcid.org/0000-0001-8323-2277

3. Hacettepe Üniversitesi Tıp Fakültesi Halk Sağlığı Anabilim Dalı, Ankara, Türkiye (1) https://orcid.org/0000-0002-9231-305X

4. Hacettepe Üniversitesi Tıp Fakültesi Halk Sağlığı Anabilim Dalı, Ankara, Türkiye (D) https://orcid.org/0000-0002-3633-4796
5. Hacettepe Üniversitesi Tıp Fakültesi Halk Sağlığı Anabilim Dalı, Ankara, Türkiye (1) https://orcid.org/0000-0003-4237-3246

6. Hacettepe Üniversitesi Tıp Fakültesi Halk Sağlığı Anabilim Dalı, Ankara, Türkiye (1) https://orcid.org/0000-0001-5865-1672

7. Hacettepe Üniversitesi Tıp Fakültesi Halk Sağlığı Anabilim Dalı, Ankara, Türkiye (i) https://orcid.org/0000-0001-9960-6982 


\section{ABSTRACT}

Aim: In this study, it was aimed to evaluate the consistency of nutrients and ingredients information given in product packaging and web pages of some chocolate products sold in supermarkets.

Materials and Methods: Total of the 88 chocolate products were found to be marketed in three different supermarkets in the Çankaya district of Ankara only 49 chocolate products were determined, containing nutrition information both on the package and web page and nutrition information of total fat and saturated fat, sugar and sugar, carbohydrate, protein, salt, energy, fiber contents per 100 grams were compared for consistency.

Results: It was found that $75.5 \%$ of the chocolate products had nutrient information on the package and $44.8 \%$ had on the website And $93.8 \%$ of the products had ingredients information on the package and $28.5 \%$ on the website. 100 grams of products contained an average of $31.8 \pm 3.76 \mathrm{~g}$ total fat and $542.7 \pm 27.40 \mathrm{kcal}$ energy. The contents of the nutrient given in the packages and websites of the products are different and the difference was found to be statistically significant $(p<0.05)$.

Conclusion: Nutrition information given on the package and web pages of the chocolate products were examined for consistency using Spearman correlation but none of the product had correlation coefficient of " $\mathrm{R}=1$ ". According to the labeling regulation, the nutritional content of all packaged foods should be specified and nutriton information of the products on packages and websites should be consistent.

Keywords: : Chocolate, nutrition label, nutrition information, website

\section{Giriş}

Beslenme ve Bulaşıcı Olmayan Hastalıklarla ilgili Viyana Deklarasyonu, Dünya Sağlık Örgütü (DSÖ) Gıda ve Beslenme Aksiyon Planı ve DSÖ Çocukluk Çağı Şişmanlığını Sonlandırma Komisyonu'nun yakın tarihli raporları ile üye ülkelere çocukların sağlıklı gıdaya ulaşmalarının desteklenmesi ve yüksek yă̆, tuz ve/veya şeker (HFSS gida) içeren yiyecekler ile gazlı içeceklerin tüketiminin azaltılması için programlar hazırlamalarını ve yaşama geçirmelerini önermiştir (1-3). Çocukluk çağı şişmanlığın HFSS gıdaların pazarlanmasından etkilendiğini gösteren kanıtlar ile DSÖ tarafından "Çocuklara Gıda ve Alkolsüz İçecekler Pazarlama Önerileri”nin üye ülkelerde uygulanmasının önemi vurgulanmaktadır. DSÖ raporuna göre; gıda pazarlamasında sıklıkla sağlıklı gıdalar yerine yüksek yağ, şeker ve/veya tuz içeren (HFSS gıdalar) sağlıksız gıda ve içeceklerin reklamları yapılarak tüketimi teşvik edilmektedir (4).

DSÖ’nün program değerlendirme raporunda Türkiye'deki şişmanlık ve sağlıksız beslenme sıklığı vurgulanmıştır (5). Türkiye 2011 yılında "Sağlıklı Beslenme ve Hareketli Hayat” programını başlatmış ve sağlıklı beslenme-fiziksel aktivite alışkanlığını geliştirme, davranış değişikliği yapma ve bu konuda toplumu bilinçlendirmeyi amaçlamıştır. Sağlıklı Beslenme ve Hareketli Hayat Programı sağlıksız beslenme ve şişmanlığın çevresel belirleyicilerini öne çıkarmıştır (6).

Şişmanlık önemli bir halk sağlığı problemidir. Yüksek enerji, şeker ve yağ içeren ürünlerin tüketimi şişmanlığın epidemisinde rol oynamaktadır. Şişmanlığa etkisi olan önemli faktörlerden biride obezojenik çevredir (7). Türkiye'de DSÖ üye ülkeleri ile birlikte gerçekleştirilmiş olan "Çocukluk Çağı Şişmanlık Çalışması-COSI” sonuçlarına göre 7-8 yaş okul çağı çocuklarda fazla kilolu ve şişmanlık prevalansı 2013 yılında \% 22.5, 2016 yılında \%24.5 olarak saptanmıştır. Dünya'da 41 milyondan fazla çocuk fazla kilolu ve şişmandır. HFSS gıdaların reklamının yapılması ve satışı obezojenik çevreyi, beslenme alışkanlığını ve şişmanlığı etkilemektedir $(8,9)$. Çocuklara Yönelik Gıda Pazarlamasının İzlenmesi (Türkiye-2018) raporuna göre televizyonda en sık yapılan reklam \%32.1 ile yiyecek ve içeceklerdir. Yiyecek-içecek reklamlarının içinde ise \%20.7 ile en sık çikolata ürünlerinin reklamı yapılmaktadır (8). 
Yaygın olarak çocuklara reklamı yapılan ve satılan çikolata yüksek enerji yoğunluğuna sahiptir $(9,10)$.

Çikolata Dünya'da en sevilen yiyeceklerinden biridir. Tropik kakao ağacının çekirdek tohumlarından yapılmaktadır, besin değeri ve enerjisi yüksektir (11). Çikolatanın insan sağlığı ve gelişimine birçok olumlu etkisinin olduğu bilimsel olarak kanıtlanmıştır. Bağışıklık ve üreme sistemine olumlu etkisi olan kakao ve çikolata, demir, selenyum, potasyum, magnezyum ve çinkodan zengindir (12).Çikolata sektörünün küresel pazar büyüklüğü 75 milyar dolardan fazladır. Avrupa Gözlem (Euromonitor)'in verilerine göre dünyada en fazla çikolata tüketimi kişi başına yıllık 9 kilogram ile İsviçre'dedir. Çikolata pazarı Türkiye'de \%10 büyüme seviyesinde olup, ylllık kişi başına düşen çikolata tüketimi ülkemizde 2.5 kilogramdır (12).

Tüketicinin sağlıklı beslenmesini sağlamak ve doğru gıdaları seçmelerini sağlayabilmek amacıyla gıda etiketi çalışmaları yapılmaktadır. Çikolatalı ürünler halk sağlığına etkileri yönünden incelenmektedir (13). Etiket; ürün hakkında tanımlayıcı bilgiler içeren ve satın alınma sırasında bu bilgilerin tüketiciye anlaşılır bir biçimde aktarılmasını sağlayan materyaldir (14). Gıda etiketleri ise "bir ürünün porsiyon, kalori, besin değeri gibi bilgilerini kapsayan ve ürün içeriği hakkında tüketiciye bilgi veren araçlardır” (13). Tarım ve Orman Bakanlığı (Gıda Tarım ve Hayvancılık Bakanlığı-2016) tarafından gıda ürünlerinde kullanılması bir zorunluluk olan etiketin içermesi gereken bilgiler "Türk Gıda Kodeksi Etiketleme Yönetmeliği” ile belirlenmiştir. Gida etiketi üzerinde, tüketicinin dikkat etmesi gereken başlıklar: ürünün son tüketim tarihi ve üretim tarihi, ürün içeriği (üretiminde kullanılan maddeler), gıda katkı maddeleri (renklendiriciler, koruyucular, aroma vericiler vb.), alerjen bilgisi, kullanım amacı yer almaktadır. Gidaların etiketleri, tanıtım ve reklam yoluyla tüketicilerin bilgilendirilmesi koşul ve kurallarını içeren, 29.11.2011 tarihinde yayınlanan Etiketleme Yönetmeliği, “Gıda Etiketleme ve Tüketicileri Bilgilendirme Yönetmeliği” ve "Beslenme ve Sağlık Beyanları Yönetmeliği” adı altında ikiye ayrılarak yeniden düzenlenmiştir (15).
Bu yönetmelikte gıdaların web sayfasındaki bilgilerle ilgili herhangi bir düzenlemeye yer verilmemiştir.

İlgili mevzuat ve yönetmeliklerde çikolatalı ürünlerin ambalajlarındaki besin ögesi ve bileşenlerinin bildirimleri ile ilgili detaylar bulunmaktadır. Yüksek doymuş yağ asidi, serbest şeker ve tuz içeren hazır gıdaların yaygın olarak tüketilmesi sağlıksız beslenme ve şişmanlığa neden olmaktadır, ayrıca bazı çikolatalı ürünlerinde kullanılan trans yağ asitlerinin de sağlığa zararlı etkileri vardır. Çikolatalı ürünlerin yüksek enerji içeriği, yaygınlaşan şişmanlık ve yüksek beden kitle indeksi (BKI) ile güçlü bir şekilde ilişkilidir (16). Bu nedenle çikolatalı ürünlerin tüketimi ve üretimleri kontrol edilmelidir (17).

Trans yağ asitleri, bazı hayvanların et ve süt ürünlerinde doğal olarak az miktarda bulunmaktadır. Ancak, yağların kısmi hidrojenasyonu sonucu oluşan ve yemeklik yağ, kızartmalar, hazır yiyecekler ve unlu mamullerin yapımında kullanılan yağların yapısında yüksek miktarda trans yağ asidi bulunmaktadır (18).

Gıda ve İlaç İdaresi (FDA), pek çok gıda maddesi için trans yağ asidi içeriği ile ilgili limitleri "Beslenme Gerçekleri Paneli”nde verilmiştir (19).

- Eğer bir gıda maddesi trans yağ asidi içeriyorsa, bu ambalajda özel bir sembolle belirtilmelidir.

- Gida ürünlerine ait ambalajlarda her bir porsiyon gıda maddesi için doymuş yağ asidi miktarının yanında trans yağ asidi miktarının da belirtilmesi gereklidir.

- “Trans yağ asidi içermemektedir” beyanı gıdadaki 100 g yağda 1 gramdan az trans yağ asidi bulunduğu durumda gıdanın ambalajında belirtilebilecektir.

Ayrica, Food and Drug Administration (FDA) 1 Ocak 2006'dan itibaren bütün gıda maddelerine ait ambalajlarda trans yağ asidi içeriğine ait bilgilerin bulundurulmasıyla ilgili kriterleri açıklamış ve tüketicilere mümkün olduğunca trans yağ asidi düşük gıdaları tercih etmelerini önermiştir. Bilimsel gelişmeler gıda endüstrisinde trans yağ asidi miktarı 
düşük gıdaların üretilmesine yönelik çalışmaların gelişmesini sağlamıştır (19).

Çalışmanın amacı; 5 farklı firmanın süpermarketlerde satılan çikolatalı ürünlerin paket ve web sayfalarındaki "besin ögeleri" ve "içerik" bilgilerinin bulunma durumunun, herhangi bir beyan (sağlıklı, enerji verir, düşük enerjili, yağsız, trans yağ içermez gibi) bulunma ve aynı ürünün ambalaj ve dijital ortamdaki "besin ögesi-içerik" bilgilerinin tutarlılık durumunun incelenmesidir.

\section{GEREÇ VE YÖNTEM}

Çalışmaya 3 süpermarkette 5-9 Haziran 2017 tarihleri arasında satışı olan 5 farklı firmanın 88 çikolatalı ürünleri (gofretli, bisküvili, fındık ve fıstıklı) çalışma kapsamına alınmış, marketlerden ambalaj fotoğrafı çekilen ürünlerin web sayfaları incelenmiş olup, ambalaj fotoğrafi çekilen 88 ürünün \%55.7’sinin (n=49) besin ögesi ve içerik bilgisinin olduğu saptanmıştır. Ürün web sayfalarında besin ögesi ve içerik bilgisi bulunmayan 39 ürün çalışma dışında bırakılmıştır.

Veri toplama ve girişi; market raflarında bulunan içeriğinde çikolata olan ürünlerinin ambalaj resimleri çekilmiştir. Meyveli ve tahıllı ürünler alınmamıştır. Ürünlerin paket ve web sayfasindaki "besin ögeleri” ve “içerik” bilgileri DSÖ Avrupa Bölgesi için hazırlanmış olan taslak protokol veri giriş setine veri girişi yapılmıştır (20).

Besin ögeleri ve içerikteki maddeler ürünlerin paket ve web sayfalarında verilen-beyan edildiği gibi alınmış ve sunulmuştur. Paket ve web sayfalarında beyan bulunma durumları, ürünlerin 100 gramlarındaki enerji (kkal), toplam yağ asidi (g), doymuş yağ asidi (g), şeker (g), karbonhidrat (g), protein (g), lif miktarları (g) paket ve web sayfasında 100 gram için verilmemiş ise ürünün 100 gramındaki miktarlar hesaplanmıştır. Ürün içindeki sodyum miktarı verilen ürünlerde verilen sodyum miktarı 0.4 ile çarpılarak ürünün içindeki tuz miktarı hesaplanarak veri setine işlenmiştir (21).

\section{Verilerin İstatistiksel Değerlendirmesi}

Araştırma tanımlayıcı tipte bir çalışmadır. Ürünlerin ambalaj ve web sayfalarından elde edilen veriler tanımlayıcı istatistiklerle ve dağılım ölçütleri ile analiz edilmiş (ortalama, standart sapma ( $\overline{\mathrm{X}} \pm \mathrm{SS}$ ), ayrıca bilgilerin benzeşme oranını tahmin etmek için кappa (к) eş uyum analizi, besin içerik verileri Wilcoxon-iki (z) eş arasındaki farkın önemlilik testi (ortalama ve standart sapma) ile analiz edilmiştir. Ambalaj ve web sayfalarında verilen bilgilerin korelasyon katsayısı Spearman korelasyon (R) analizi ile hesaplanmıştır. Korelasyon analizinde $\mathrm{R}$ değeri “1”e yaklaştıkça korelasyon artmaktadır. Ambalajda verilen bilgi web sayfasında verilmemiş ise o ürün "iki eş arasında" analiz yapılamaması nedeniyle analizlerden çıkartılmak zorunda kalınmıştır. Bu nedenle analizlerde sayılar farklıdır. Analizler SPSS 23.0 programında yapılmış olup çalışmanın anlamlılık düzeyi $a=0.05$ 'tir. Çalışmada incelenen çikolatalı ürünlerin isim ve firmaları etik olarak verilmemiştir. Firmalar 1-5 olarak kodlanmış ve bulgularda bu kodlarla sunulmuştur.

\section{BULGULAR}

Araştırma kapsamında Türkiye'deki 5 farklı firmaya ait 49 çikolatalı ürünlerin ambalaj ve web sayfalarındaki beyan, bilgi ve besin ögesi bilgileri incelenmiş ve Tablo 1'de sunulmuştur. Ürünlerin ambalajlarındaki ve web sayfalarındaki içindekiler, enerji-besin ögesi tablosu ve beyanlarına bakıldığında; enerji-besin ögesi bilgisi ürünleri \%75.5'inin ambalajlarında \%44.9'unun web sayfasında, içindekiler bilgisi ambalajların \%93,8'inde, web sayfalarının \%28.6'sında yer almaktadır. Beslenme beyanının olup olmadığı incelendiğinde ürünlerin tamamının ambalajında "beyan” bulunduğu, ürün web sayfalarının \%28.6' sında "beyan” bilgisi verildiği saptanmıştır. Firma 1'in ürünlerinin tamamının (\%100) ambalajında; içindekiler, enerji-besin ögesi tablosu ve beyan mevcutken aynı ürünlerin web sayfalarında sadece enerji-besin ögesi tablosu bulunmaktadır (Bu bulgular tablo olarak verilmemiştir.). Firma 2, 3 ve 4'ün 
ürünlerinin ambalaj ve web sayfasında içindekiler, enerji-besin ögesi tablosu ve beyan mevcuttur. Firma 5'in ürünlerinin tamaminın ambalajında içindekiler ve beyan yazılmış, enerji-besin tablosu etikete yazılmamış olup ürünlerin web sayfalarında incelenen konularla ilgili bilgi bulunmamıştır

Ürün ambalajında en fazla verilen besin içeriği bilgisi emülgatördür ve ambalajların \%93.9'unda, web sayfalarının \%28.6'sinda bu bilgi mevcuttur. En az bilgi verilen ürün mısır nişastası olup ambalajda \%14.3, web sitesinde \%6.2 sıklıkta verilmiştir. Ürünlerin ambalaj ve web sayfalarında bilgi verilme durumları \%100.0 olan ürün bulunmamaktadır. Soya ürünü, yumurta ve glikoz için bilgi ambalajda verilmiş ancak aynı ürünün web sayfasında hiç bilgi verilmemiştir. Kakao kitlesi, bitkisel yağ, peynir altı suyu tozu, sodyum amonyak karbonat, tam hidrojenize bitkisel yağ ve mısır nişastasının ürün içinde olma durumunun ürün ambalaj ve web sayfalarında verilme sıklığı istatistiksel olarak farklıdır $(\mathrm{p}<0.05)$. Emülgatör, kakao kuru maddesi, kakao yağı, kuruyemiş, aroma verici, süt tozu, glüten ve kakao kitlesinin üründe bulunup bulunmama bilgileri de ambalaj ve web sayfalarında farklı sıklıklarda verilmiş olup istatistiksel olarak anlamlı değildir ( $p>0.05$ ) (Tablo 1).

İncelenen çikolatalı ürünlerin ambalaj ve web sayfalarında besin ögesi bulunma durumları Tablo 2'de verilmiştir. Kırk dokuz çikolatalı ürünün \%75.5'inin ambalajında ürünün her 100 gramındaki toplam yağ asidi, karbonhidrat, protein ve enerji içerikleri belirtilmiştir. Web sayfalarında aynı ürünlerin \%44.8'inin besin içeriğini verilmiştir. Ürünlerin \% 67.3'ünün ambalajında, \%28.5'inin web sayfasında doymuş yă̆ asidi miktarı, \%87.7’sinin ambalajında, \%44.8'inin web sayfasında şeker miktarı, ambalajların \%67.3'ünde, web sayfalarının \% 44.8'inde tuz miktarl, ürünlerin 100 gramında bulunan lif miktarları ise ambalajların \%63.2'sinde, web sayfalarının \%42.8'inde belirtilmiştir. Trans yă asidi miktarı ürünlerin ambalajlarının \%18.3’ünde

Tablo 1. Bazı çikolatalı ürünlerde ürün içeriğindeki bazı katkı maddelerinin ambalaj ve web sayfalarında bulunma durumları

\begin{tabular}{|c|c|c|c|c|c|c|c|c|c|}
\hline \multirow{3}{*}{ İçindekiler } & \multicolumn{4}{|c|}{ Ambalaj } & \multicolumn{4}{|c|}{ Web sayfası } & \multirow{3}{*}{ карра } \\
\hline & \multicolumn{2}{|c|}{ Var } & \multicolumn{2}{|c|}{ Yok } & \multicolumn{2}{|c|}{ Var } & \multicolumn{2}{|c|}{ Yok } & \\
\hline & $\mathbf{S}$ & $\%$ & $\mathbf{S}$ & $\%$ & $\mathbf{S}$ & $\%$ & $\mathbf{S}$ & $\%$ & \\
\hline Emülgatör & 46 & 93.9 & 3 & 6.1 & 14 & 28.6 & 35 & 71.4 & 0.258 \\
\hline Kakao kuru maddesi & 44 & 89.8 & 5 & 10.2 & 14 & 28.6 & 35 & 71.4 & 0.136 \\
\hline Kakao yağı & 43 & 87.7 & 6 & 12.3 & 13 & 26.5 & 36 & 73.5 & 0.116 \\
\hline Kuruyemiş & 43 & 87.8 & 6 & 12.2 & 11 & 22.4 & 38 & 77.6 & 0.159 \\
\hline Aroma verici & 42 & 85.7 & 7 & 14.3 & 14 & 28.6 & 35 & 71.4 & 0.071 \\
\hline Süt tozu & 39 & 79.6 & 10 & 20.4 & 10 & 20.4 & 39 & 79.6 & 0.073 \\
\hline Gluten & 38 & 77.5 & 11 & 22.5 & 8 & 16.3 & 41 & 83.7 & 0.096 \\
\hline Kakao kitlesi & 23 & 46,9 & 26 & 53.1 & 13 & 26.5 & 36 & 73.5 & 0.000 \\
\hline Bitkisel yağ & 21 & 42.8 & 28 & 57.2 & 4 & 8.2 & 45 & 91.8 & 0.016 \\
\hline Peynir altı suyu tozu & 21 & 42.8 & 28 & 57.2 & 8 & 16.3 & 41 & 83.7 & 0.000 \\
\hline Soya ürünü & 12 & 24.5 & 37 & 75.5 & - & - & 49 & 100.0 & $*$ \\
\hline Yumurta & 12 & 24.5 & 37 & 75.5 & - & - & 49 & 100.0 & $*$ \\
\hline Sodyum amonyak karbonat & 12 & 24.5 & 37 & 75.5 & 5 & 10.2 & 44 & 89.8 & 0.000 \\
\hline Tam hidrojenize bitkisel yağ & 9 & 18.4 & 40 & 81.6 & 4 & 8.2 & 45 & 91.8 & 0.000 \\
\hline Glukoz & 8 & 16.3 & 41 & 83.7 & - & - & 49 & 100.0 & $*$ \\
\hline Mısır nişastası & 7 & 14.3 & 42 & 85.7 & 3 & 6.2 & 46 & 93.8 & 0.000 \\
\hline Toplam & 37 & 75.5 & 12 & 24.6 & 22 & 44.9 & 27 & 55.1 & \\
\hline
\end{tabular}

*Analiz yapılamamıştır. 
Tablo 2. Bazı çikolatalı ürünlerin besin ögeleri ve enerji ambalaj ve web sayfalarında bulunma durumları.

\begin{tabular}{|c|c|c|c|c|c|c|c|c|}
\hline \multirow{3}{*}{ İçindekiler } & \multicolumn{4}{|c|}{ Ambalaj } & \multicolumn{4}{|c|}{ Web sayfası } \\
\hline & \multicolumn{2}{|c|}{ Var } & \multicolumn{2}{|c|}{ Yok } & \multicolumn{2}{|c|}{ Var } & \multicolumn{2}{|c|}{ Yok } \\
\hline & $\mathbf{S}$ & $\%$ & S & $\%$ & S & $\%$ & $\mathrm{~S}$ & $\%$ \\
\hline Toplam yağ asidi & 37 & 75.5 & 12 & 24.5 & 22 & 44.8 & 27 & 55.2 \\
\hline Doymuş yağ asidi & 33 & 67.3 & 17 & 34.7 & 14 & 28.5 & 35 & 71.5 \\
\hline Trans yağ asidi & 9 & 18.3 & 40 & 81.7 & - & - & 49 & 100.0 \\
\hline Karbonhidrat & 37 & 75.5 & 12 & 24.5 & 22 & 44.8 & 27 & 55.2 \\
\hline Şeker & 43 & 87.1 & 6 & 12.9 & 22 & 44.8 & 27 & 55.2 \\
\hline Protein & 37 & 75.5 & 12 & 24.5 & 22 & 44.8 & 27 & 55.2 \\
\hline Enerji & 37 & 75.5 & 12 & 24.5 & 22 & 44.8 & 27 & 55.2 \\
\hline Tuz & 33 & 67.3 & 17 & 34.7 & 22 & 44.8 & 27 & 55.2 \\
\hline
\end{tabular}

Tablo 3. Bazı çikolatalı ürünlerin ambalaj ve web sayfalarında verilen enerji-besin ögesi ortalamaları ( $\mathrm{g} / 100 \mathrm{~g})$.

\begin{tabular}{|c|c|c|c|c|}
\hline \multirow{2}{*}{ Enerji-besin ögesi içeriği (g/100g) } & Ambalaj & Web sayfası & \multirow{2}{*}{$\mathbf{Z}$} & \multirow{2}{*}{$\mathbf{p}$} \\
\hline & $\overline{\mathrm{X}} \pm \mathrm{SS}$ & $\overline{\mathrm{X}} \pm \mathrm{SS}$ & & \\
\hline Toplam yağ asidi $(\mathrm{n}=21)$ & $31.8 \pm 3.76$ & $31.6 \pm 4.39$ & -1.069 & 0.28 \\
\hline Doymuş yağ asidi $(n=14)$ & $20.9 \pm 10.45$ & $16.2 \pm 4.25$ & -1.633 & 0.10 \\
\hline Şeker $(n=22)$ & $41.9 \pm 9.40$ & $43.5 \pm 7.73$ & -1.826 & 0.06 \\
\hline Karbonhidrat $(\mathrm{n}=22)$ & $53.7 \pm 6.72$ & $53.3 \pm 7.03$ & -1.069 & 0.28 \\
\hline Protein $(n=22)$ & $9.0 \pm 6.21$ & $9.9 \pm 7.95$ & -1.826 & 0.06 \\
\hline Tuz $(n=21)$ & $0.3 \pm 0.25$ & $0.3 \pm 0.27$ & -1.095 & 0.27 \\
\hline Enerji (kkal) $(\mathrm{n}=22)$ & $542.7 \pm 27.43$ & $536.2 \pm 20.32$ & -1.069 & 0.28 \\
\hline Lif $(n=21)$ & $4.8 \pm 3.27$ & $4.4 \pm 2.81$ & -1.633 & 0.10 \\
\hline
\end{tabular}

verilmiş aynı ürünlerin web sayfalarında trans yağ asidi bilgisi bulunamamıştır (Tablo 2).

Ürünlerin ambalajlarında ve web sayfalarında verilen her 100 gramlarındaki besin ögesi içerik miktarları benzerdir (Tablo 3). Bir ürünün 100 gramında ortalama 53.77 g karbonhidrat, 20.92 g doymuş yağ, $41.97 \mathrm{~g}$ ilave şeker, $0.33 \mathrm{~g}$ tuz ve $542.77 \mathrm{kkal}$ enerji bulunmaktadır.. Ürünün 100 gramında ortalama 31.85 g toplam yağ asidi bulunmakla birlikte toplam yağın ortalama 20.92 gramı doymuş yağ asidinden gelmektedir. Ürün ambalaj ve web sayfalarında verilen besin içerikleri ürünün HFSS gıda olduğunu göstermektedir (22).

Ürünlerin ambalajlarında ve web sayfalarında verilen enerji-besin ögesi içeriklerinin korelasyon katsayısı hesaplanmış ve Tablo 4'te verilmiştir. Ambalaj ve web sayfalarında verilen bilgilerin korelasyon katsayısı bir $(\mathrm{R}=1)$ yani içerik bilgileri tamamen aynı olan ürün yoktur (Tablo 4). Aynı ürünün ambalaj ve web sayfasında tüketiciye sunulan besin ögesi ve içindekiler bilgilerinin aynı olması tüketiciyi tam ve doğru bilgilendirme yönünden önemlidir. Trans yağ asidi miktarı ürünlerin \%18.3'ünün ambalajında belirtilirken, ürün web sayfalarında trans yağ asidi içeriği ile ilgili bilgi verilmemiştir. Toplam yağ asidi, protein, enerji ve lif değerleri ürünün web sayfasında ürün ambalaj etiketine göre fazla, doymuş yağ asidi, şeker, karbonhidrat ve tuz miktarları ürünün web sayfasında ürün ambalaj etiketinde verilen içerik miktarlarına göre daha az olarak verilmiştir. Ürün ambalaj-web sayfası besin içeriği tutarlılığının en yüksek olduğu besin maddesi protein (0.981) en az olduğu besin maddesi ise tuzdur (0.769). İncelenen çikolatalı ürünlerin ambalaj ve web sayfalarında verilen enerji ve besin ögeleri bilgileri Spearman korelasyonla incelendiğinde korelasyon katsayısı R=1 olan ürün saptanmamıştır (Tablo 4). 
Tablo 4. Bazı çikolatalı ürünlerin ambalaj ve web sayfalarındaki besin ögesi içerikleri korelasyonu.

\begin{tabular}{lcc}
\hline Besin içerikleri & Spearman $\mathbf{R}$ & $\mathbf{p}$ \\
\hline Toplam yağ asidi $(\mathrm{n}=21)$ & $0.978 \pm 0.018$ & 0.000 \\
Doymuş yağ asidi $(\mathrm{n}=14)$ & $0.922 \pm 0.088$ & 0.000 \\
Şeker $(\mathrm{n}=22)$ & $0.967 \pm 0.031$ & 0.000 \\
Karbonhidrat $(\mathrm{n}=22)$ & $0.962 \pm 0.030$ & 0.000 \\
Protein $(\mathrm{n}=22)$ & $0.981 \pm 0.016$ & 0.000 \\
Tuz $(\mathrm{n}=21)$ & $0.769 \pm 0.135$ & 0.000 \\
Enerji $(\mathrm{n}=22)$ & $0.955 \pm 0.044$ & 0.000 \\
Lif $(\mathrm{n}=21)$ & $0.969 \pm 0.031$ & 0.000 \\
\hline
\end{tabular}

\section{TARTIŞMA}

Bu çalışmada bazı süpermarketlerde satılan çikolatalı ürünlerin ambalaj ve web sayfalarındaki "besin ögeleri”, “içerik” ve "beyan” bulunma durumları ve ürün ambalaj-web sayfalarında verilen bilgilerin tutarlılığı incelenmiştir. İncelenen çikolatalı ürünlerin ambalajlarındaki içerik bilgisi ürünlerin web sayfasına göre daha fazladır. Ürünlerin \%55.1'inin web sayfasında ürün içeriği (enerji-besin ögesi tablosu ve içindekiler bilgisi) verilmemiştir. Gıda ürünlerinin ambalaj ve web sayfalarında tüketiciye tam bilgi verilmesi sağlıklı beslenme ve tüketicinin bilinçlendirilmesi açısından önemlidir.

Ürünlerin içindekiler bilgisi incelenen 49 ürünün \%93.8'inin ambalajında vardır, ancak aynı ürünlerin, \%53.0'ının web sayfasında içindekiler bilgisi verilmemiştir. Enerji-besin ögesi tablosu ürünlerin \%75,5'inin ambalajinda, \%44.9'unun web sayfasinda bulunmaktadır. Besler ve arkadaşlarının (23) Türkiye genelinde yaptığı çalışmada marketlerde satılan ambalajlı ürünlerin \%74.0'ının ambalajında enerjibesin ögesi tablosunun yer aldığı gösterilmiştir. Besler ve arkadaşlarının yapmış olduğu çalışma bulguları ile çalışmamızın ürün ambalajlarında enerji-besin öğesi tablosunun verilmiş olması benzerlik göstermektedir.

Tüm gıda ürünlerinde olduğu gibi çikolatalı ürünlerin ambalajlarında paylaştıkları bilgiler tüketiciler için büyük önem taşımaktadır $(11,15)$. Türkiye'de üniversite öğrencileri ve çalışanlarında yapılan Birleşmiş Milletler İlerleyen Gıda Etiketlemesi Yaşam için Daha İyi Eğitim (Food Labelling to Advance
Better Education for Life-FLABEL) çalışması, mısır gevrekleri arasında seçim yaparken katılımcıların \%48'inin 'içindekilere”, \% 18'inin ise "etikete" göre seçim yaptıklarını ve katılımcıların en sık olarak pratikte etiketteki besin ögesi bilgilerini kullandıklarını çalışma sonuçlarında göstermişlerdir (24). Güneş ve arkadaşlarının (13) yaptığı çalışmada, 40 gıda ürününe ait etiketler incelenmiş ve özellikle sağlık bilgisi, besin değeri veya günlük ihtiyacı karşılama oranı bilgilerinin bulunmadığı çalışmada saptanmıştır. Tüketiciyi bilgilendirmek için ürün etiketlerinde besin ögesi, içindekiler, günlük ihtiyacı karşılama yüzdesi, ürünü tüketilmesi önerilmeyen durumlar ve sağlığa olan olumlu ve olumsuz etkileri verilmelidir.

$\mathrm{Bu}$ çalışmada çikolatalı ürünlerin enerji-besin ögesi ve içerik bilgilerinde, tam hidrojenize bitkisel yağ, bitkisel yağ, kakao kitlesi, mısır nişastası, sodyum amonyak karbonat ve peynir altı suyu tozunun olup olmadığ bilgisinin ürünlerin ambalajlarında ve web sayfalarında farklı verildiği saptanmıştır. Ambalaj ve web sayfalarında tüketiciye sunulan bilgilerin birbirinden farklı olması tüketicilerin doğru bilgiye ulaşmasını etkilediği, Güneş ve arkadaşlarının (13) çalışmasında gösterilmiş olup tüketiciler arasında etiket okuma alışkanlığı sıklığı \%56'dır ve katılımcılar etiketteki bilgilerin yeterince denetlenmediği düşüncesi ile etikete güven duymamaktadırlar. Çalışmamızın bulguları da etiket bilgilerinde eksiklikyetersizlik olduğu göstermektedir. 
$\mathrm{Bu}$ çalışma sonuçlarına göre ürünlerin \%18.3'ünün ambalajında trans yağ asidi miktarı verilmiş olup ancak ürünlerin web sayfalarında trans yağ asidi ile ilgili herhangi bilgi yoktur. Oysaki Türk Gıda Kodeksi Gıda Etiketleme ve Tüketicileri Bilgilendirme Yönetmeliği’ne (2017) göre trans yağlar zorunlu beslenme bildiriminin yapilması gereken içeriklerdendir. (25). Çocuk ve gençlerin yüksek miktarlarda tükettiği gidalarda bulunan trans yağ asitlerinin fazla tüketimi bireyin kan kolesterolünü, tip 2 diyabet ve koroner kalp hastalığı riskini artırdığından, ambalajlı gıda kaynaklı trans yağ asidi tüketiminin en aza indirilmesi veya tamamen engellenmesi gerekmektedir. Bu nedenle gidalardaki trans yağ asidi düzeylerinin belirlenmesi, izlenmesi ve tüketicinin bilgilendirilmesi önemlidir (26).

\section{SONUÇ VE ÖNERİLER}

İncelenen çikolatalı ürünlerin besin ögesi, enerji, içindekiler ve beyan bilgileri ürünlerin ambalajlarında ve web sayfalarında farklıdır. Tüm ambalajlı gıdalarda olduğu gibi çikolatalı ürünlerin alımında etkili olan ürün içerikleri, ambalajlarda ve web sayfasında belirtilmeli ve verilen bilgiler birbiri ile tutarlı olmalıdır. Gıda etiketleri tüketicinin sağlıklı gıdaya ulaşımının sağlanmasında ve sağlıklı bir toplumun oluşmasında önemli rol oynamaktadır. Etiketlemeye yönelik araştırmalar tüm gıda çeşitlerinde yapılmalı ve gerekli politikalar geliştirilmelidir. Özellikle ürün web sayfalarındaki ürün bilgilerinde tutarlığın artırılması için yasal düzenlemeler yapılması tüketici sağlığını koruyucu olacaktır. Çikolatalı ürünlerin üretim, paketleme, etiketleme, tanıtım basamaklarıyla ilgili denetimlerin arttırılması, ürünlerin sağlığa etkileri, etiket okumanın önemi, trans yağ asitlerinin sağlığa olumsuz etkileri ile ilgili farkındalığının geliştirilmesi ve arttırılması için çalışmaların yapılması, özellikle beslenmeye bağlı kronik hastalıkların temeli olan çocukluk çağı şişmanlığın önlenmesi için önemlidir. İşlem görmüş gıdalarla ilgili etiket, satış ve reklam düzenlemeleri ve de yüksek yağ, şeker ve tuz içeren gıdalarda vergi artışları yapılarak şişmanlık ve sağlık için riskli olan gıdaların satın alma ve tüketimlerinin azaltılması önemlidir.
$\mathrm{Bu}$ çalışmanın sonuçları Haziran 2017 tarihini yansıtmaktadır. Tanımlayıcı çalışma olması nedeniyle sonuçlar incelenen ürünlerin ve ürün web sayfalarının Haziran 2017 verilerinden alınan sonuçlarla kısıtlıdır.

Çıkar çatışması - Conflict of interest: Yazarlar çıkar çatışması olmadığını beyan ederler. - The authors declare that they have no conflict of interest.

\section{KAYNAKLAR}

1. World Health Organization (WHO). Vienna declaration on nutrition and noncommunicable diseases in the context of Health 2020. Copenhagen: WHO Regional Office for Europe. July 5, 2013. Available at: http:// www.euro.who.int/_data/assets/pdf_file/0005/193253/ CONSENSUS-Vienna-Declaration-5-July-2013.pdf. Accessed September 11, 2019.

2. World Health Organization (WHO). European food and nutrition action plan 2015-2020. Copenhagen: WHO Regional Office for Europe; September 15-19, 2014. Available at: http://www.euro.who.int/_data/assets/ pdf_file/0008/253727/64wd14e_FoodNutAP_140426.pdf. Accessed September 11, 2019.

3. World Health Organization (WHO). Commission on Ending Childhood Obesity. Geneva: WHO; 2016. Available at: https://apps.who.int/iris/bitstream/ handle/10665/204176/ 9789241510066_eng.pdf; jsessionid $=$ B6CF5251E21003E8769BC1579AA7D164? sequence=1. September 11, 2019.

4. Kelly B, Halford JC, Boyland EJ, Chapman K, BautistaCastaño I, Berg C, et al. Television food advertising to children: a global perspective. AJPH. 2010;100(9):1730-6.

5. World Healt Organization (WHO).Turkish Healthy Nutrition and Active Life Programme 2010-2014 and related initiatives An evaluation of progress since the WHO Ministerial Conference on Counteracting Obesity. Copenhagen: WHO Regional Office for Europe; 2016. Available at: http://www.euro.who.int/_data/assets/ pdf_file/0014/333212/HNAP-Turkey.pdf?ua=1. Accessed September 11, 2019.

6. T.C Sağlık Bakanlığı Temel Sağlık Hizmetleri Genel Müdürlüğü. Türkiye Sağlıklı Beslenme ve Hareketli Hayat Programı, 2010-2014. Ankara, 2011. Erişim: https://www.tuseb.gov.tr/enstitu/tacese/yuklemeler/ ekitap/Beslenme/obezite_ve_fiziksel_aktivite_egitim_ modulleri.pdf. Erişim tarihi: 11 Eylül 2019.

7. Güzel S, Keser A, Hatun Ş. The hidden danger in packaged beverages sold in supermarkets. IJFSN. 2017;2(5):48-52.

8. Helleve A, Sandberg H, Berg C, Prell H, Ólafsdóttir S, Gísladóttir E, et al. Monitoring food marketing 
to children: A joint Nordic monitoring protocol for marketing of foods and beverages high in fat, salt and sugar (HFSS) towards children and young people. TemaNord 2018:504.

9. Özcebe H, Bağcı Bosi T, Yardım MS, Yardım N. Türkiye Çocukluk Çaği (İlkokul 2. Sinif Öğrencilerde) Şişmanlik Araştırması COSI-TUR 2016. Ankara: Sağlık Bakanlığı. 2017. Rapor No.: 1080.

10. Özcebe H, Bağcı Bosi AT, Keskinkılıç B, Yardım N, Çelikay N, Çelikcan E. Çocukluk Çağı (7-8 Yaş) Şişmanlık Araştırması 2013 (COSI-TUR-2013). Ankara: Sağlık Bakanlığı. 2014. Rapor No.: 920.

11. Tokuşoğlu Ö. Kakao, Çikolata ve Sağlık. Gıda 2000 Gıda Teknolojsi ve Tarım Dergisi [İnternet]. 2017. Erişim: http://www.gida2000.com/kakao-cikolata-ve-saglik. html. Erişim tarihi: 11 Eylül 2019.

12. Kayri M, Günüç $S$. The adaptation of internet addiction scale into Turkish: The study of validity and reliability. Ankara University, JFES. 2009;42(1):157-75.

13. Güneş FE, Aktaç Ş, Korkmaz B. Tüketicilerin Gida Etiketlerine Yönelik Tutum ve Davranışları. AFJ. 2014;12(3).

14. Pride WM, Ferrell OC. Foundations of Marketing. Mason, OH, USA: South-Western: Cengage Learning. Available at: https:/trove.nla.gov.au/ work/ 9675639? q\&sort $=$ holdings + desc\&_ $=1553778784481 \&$ versionId $=$ 179772173. Accessed September 11, 2019.

15. Number of smartphone users worldwide from 2014 to 2020 (in billions). The Statistics Portal 2019 Available at: https://www.statista.com/statistics/330695/number-ofsmartphone-users-worldwide/. Accessed September 11, 2019.

16. Güzel S, Keser A, Hatun Ş. Investigating the nutritional value of foods targeting children. EWD-SABO. 2018:1-8.

17. Kuralan M, Yorulmaz A, Ercoşkun H. Trans yağ asitleri kaynakları ve insan sağllğ̆ üzerine etkileri. JFFST. 2005;(7).

18. Kahraman SD, Küplülü Ö. Trans yağ asitleri. VHDD.
2011;82(2):15-24.

19. Kantarcı Ö, Özalp M, Sezginsoy C, Özaşkınlı O, Cavlak C. Dijitalleşen Dünyada Ekonominin İtici Gücü: E-Ticaret. TÜSİAD; 2017. Rapor No.: TÜSİAD-T/2017, 04-587.

20. World Health Organization (WHO). Bağcı Bosi T, Ergüder T, Breda J, Jewell J. Monitoring food marketing to children in Turkey 2018. Ankara: World Health Organization Country Office in Turkey; 2018. Available at: http:// www.euro.who.int/_data/assets/pdf_file/0007/381823/ food-marketing-tur-eng.pdf?ua=1. Accessed September 11, 2019.

21. Tayfur M ve ark. Tüketiminin Azaltılması Gereken Besin ve Besin Ögeleri, Pekcan AG, Şanlıer N, Baş M, editörler. Türkiye Beslenme Rehberi 2015 (TÜBER). 1. Baskı. Ankara: Kayhan Ajans; 2016.p..67-72.

22. Pan Americen Health Organization (PAHO). PAHO define excess level of sugar, salt and fat in processed food and drink products. Washington: PAHO/WHO meetings; 19 February 2016. Available at: https://www.paho.org/ hq/index.php?option=com_content\&view=article\& id=11685:2016-paho-defines-excess-levels-of-sugar-saltand-fat-in-processed-food-drink\&Itemid=1926\&lang=en Accessed November 19, 2019.

23. Besler HT, Buyuktuncer Z, Uyar MF. Consumer understanding and use of food and nutrition labeling in Turkey. JNEB. 2012;44(6):584-91.

24. Akgüngör S, Van Trijp H, Van Herpen E, Gülcan Y, Kuştepeli Y. Gıda etiketlerine yönelik dikkat ve algı: Dokuz eylül üniversitesi'nde uygulanan göz hareketleri izleme deneyi sonuçları. DEUSBED. 2011;13(3):7-18.

25. T.C. Gıda, Tarım ve Hayvancılık Bakanlığı, Türk Gıda Kodeksi Gida Etiketleme ve Tüketicileri Bilgilendirme Yönetmeliği. Resmî Gazete:26.01.2017-29960 (Mükerrer). Erişim: https://www.resmigazete.gov.tr>eskiler>2017/01 Erişim tarihi: 11 Eylül 2019.

26. Demir BA. Trans yağ asidi içermez beyanı bulunan bazı endüstriyel gidaların yağ asidi profilleri [Yüksek Lisans Tezi]. Namık Kemal Üniversitesi, Tekirdağ; 2011. 